Jurnal Kesehatan Perintis (Perintis's Health Journal) 7 (1) 2020: 8-15

Contents list available at JKP website

Jurnal Kesehatan Perintis (Perintis's Health Journal)

Journal homepage: https://jurnal.stikesperintis.ac.id/index.php/JKP

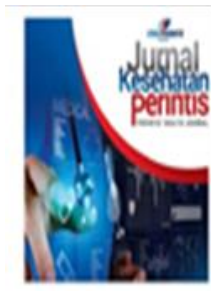

\title{
Emotional Freedom Technique (EFT) Menurunkan Kecemasan Ibu Yang Memiliki Bayi Berat Lahir Rendah (BBLR)
}

\section{Anisa Oktiawati*, Ita Nur Itsna, Jumrotun Ni’mah}

\author{
Sekolah Tinggi Ilmu Kesehatan Bhakti Mandala Husada Slawi, Jawa Tengah, Indonesia
}

Article Information :

Submission:Jun 9, 2020; Revised:Jun 30, 2020; Accepted:Jul 1, 2020; Available online: Jul 12, 2020

*Corresponding author : rajendraadhyazkawidodo@gmail.com

\begin{abstract}
ABSTRAK
Kasus Bayi Berat Lahir Rendah (BBLR) merupakan salah satu kontribusi terhadap kematian bayi khususnya pada masa perinatal sehingga membutuhkan perawatan dan perhatian khusus sehingga menimbulkan perasaan cemas pada ibu karena setiap ibu yang setelah melahirkan. Salah satu cara mudah untuk mengurangi kecemasan yaitu dengan terapi Emotional Freedom Technique (EFT). Data rekam medis RSUD dr. Soeselo Kabupaten Tegal kasus BBLR dari Bulan Januari sampai September 2019 sejumlah 421 kasus. Tujuan penelitian ini adalah mengetahui tingkat kecemasan sebelum dan sesudah penerapan EFT. Penelitian ini menggunakan quasi experimental dengan rancangan penelitian menggunakan One group pra-post test design. Sampel dalam penelitian ini adalah $28 \mathrm{lbu}$ yang memiliki BBLR. Alat ukur kecemasan menggunakan kuesioner yang diadopsi dari Hamilton Rating Scale for Anxiety (HRS-A). Uji statistik yang digunakan adalah uji wilcoxon. Hasil uji statistik di dapatkan $p$ value 0,000 artinya ada pengaruh EFT terhadap tingkat kecemasan pada ibu yang memiliki BBLR.
\end{abstract}

Kata Kunci : BBLR, Emotional Freedom Technique, Kecemasan

\section{ABSTRACT}

The Case of Low Birth Weight Babies (LBW) is one of the contributions to the death of infants especially during the perinatal period so that it requires special care and attention so as to cause feelings of anxiety in the mother because every mother after childbirth. One easy way to reduce anxiety is by Emotional Freedom Technique (EFT) therapy. Medical records of RSUD dr. Soeselo Tegal District, LBW cases from January to September 2019 were 421 cases. This research uses quasi experimental research design using One group pre-post test design. The sample in this study were 28 mothers who had LBW. Anxiety measurement tool uses a questionnaire adopted from the Hamilton Rating Scale for Anxiety (HRS-A). The statistical test used was the Wilcoxon test. Statistical test results obtained $p$ value 0,000 means that there is an effect of EFT on the level of anxiety in mothers who have LBW.

Keywords: LBW, Emotional Freedom Technique, Anxiety

\section{PENDAHULUAN}

Kasus Bayi Berat Lahir Rendah (BBLR) di Indonesia mencapai $84,1 \%$ dan di Jawa Tengah mencapai 95,3\% (Riskesdas, 2018).
Kelahiran BBLR sebagian disebabkan oleh lahir sebelum waktunya (prematur), dan sebagian oleh karena mengalami gangguan pertumbuhan selama masih dalam kandungan. 
Kondisi BBLR menuntut penyesuaian orang tua terhadap pengasuhan bayinya. Kasus BBLR sering kali memerlukan perawatan yang intensif sampai bayi stabil dan siap untuk mendapatkan perawatan di rumah. Bayi ini secara umum berada di ruangan khusus yang terpisah dengan ruang perawatan ibu. Perpisahan ini dapat menyebabkan kecemasan pada ibu tentang kondisi bayinya (Saidah et al., 2011).

Ibu yang memiliki BBLR akan mengalami stress pada fase kehidupan ibu dan bayinya (Laas MJ et al, 2011). Lingkungan ruang intensif diidentifikasi meliputi lingkungan fisik (suara, cahaya, penanganan, peralatan), lingkungan psikologis (perkembangan bayi, stres pemberi asuhan) dan dukungan tenaga kesehatan di NICU (keterlibatan pemberi asuhan, peran perawat) (Hunt, 2011).

Salah satu cara untuk menurunkan kecemasan pada ibu yang memiliki BBLR adalah menggunakan terapi emotional freedom techniques (EFT). EFT dilakukan dengan empat langkah yaitu set up, sequence, 9 gamut procedure dan pengulangan. Pada langkah pertama dilakukan pengusapan pada area yang sakit, kemudian dilakukan ketukan, setelah itu pasien dianjurkan untuk fokus pada pikiran permasalahan yang dihadapi. Proses set up yang dilakukan dapat mempengaruhi alam bawah sadar manusia dengan cara memberikan sugesti pada diri sendiri. Sumber kecemasan tersebut itulah yang akan dijadikan kalimat afirmasi pada saat melakukan tapping. Setelah itu dilakukan ketukan pada 9 titik gamut (gerakan mata) dan dapat djulangi kembali untuk merangsang keseimbangan otak kiri dan kanan serta mengatasi masalah kecemasan seseorang (Thahir et al, 2014).

Keadaan relaksasi akan dapat berpengaruh pada kondisi mental pasien serta menurunkan ketegangan otot-otot karena terjadi interaksi dari hormon psikoneuroendokrin dan dapat menurunkan produksi katekolamin, sehingga menimbulkan suasana yang nyaman dan menurunkan perasaan cemas (Haruyama, 2014). Produksi hormon endorfin yang terjadi pada proses EFT bisa dihasilkan dari efek relaksasi pasien yang ada dan juga tapping yang dilakukan pada pasien (Karatzias, T. et al, 2011) ; (Bougea, A. et al, 2013).

Penelitian yang dilakukan ini berbeda dengan penelitian sebelumnya. Penelitian sebelumnya dari Shari et al., (2014) meneliti tentang Emotional Freedom Technique (EFT) dan tingkat kecemasan pasien yang akan menjalani Percutaneous Coronary Intervention dan Penelitian yang dilakukan oleh Ningsih, Karim, \& Sabrian, (2015) tentang efektivitas terapi Emotional Freedom Technique (EFT) terhadap kecemasan pasien kanker payudara stadium II dan III berbeda dengan penelitian yang diteliti oleh penulis. Penelitian yang dilakukan oleh peneliti adalah kecemasan pada ibu yang memiliki BBLR sedangkan penelitian sebelumnya meneliti kecemasan pada pasien yang menjalani Percutaneous Coronary Intervention dan kecemasan pasien kanker payudara stadium II dan III . Penelitian lain juga dilakukan oleh (Isworo et al., 2019) tentang pengaruh Emotional Freedom Technique (EFT) dalam menurunkan tekanan darah pada lansia hipertensi,subyek penelitian ini adalah lansia yang mengalami hipertensi dengan teknik pengambilan sampel adalah consecutive sampling, sedangkan pada penelitian yang peneliti lakukan adalah meneliti ibu yang memiliki BBLR dengan teknik pengambilan sampel adalah total sampling.

Kasus BBLR menjadi salah satu kasus bayi yang bermasalah dan harus diberikan perawatan intensif. Data rekam medis RSUD dr. Soeselo Kabupaten Tegal menunjukkan data kasus BBLR dari Bulan Januari sampai September 2019 sejumlah 421 kasus dan ratarata perbulan terdapat 40 kasus dengan penyebab terbanyak karena lahir kurang bulan atau lahir lebih awal dari perkiraan lahirnya (preterm). Data lain menunjukkan bahwa angka kejadian BBLR pada tahun 2018 sebanyak 511 kasus dan tahun 2017 sebanyak 528 kasus.

Menurut Hendiyanto (2014) pada kasus BBLR bayi dirawat di rumah sakit untuk mendapatkan perawatan intensif dengan waktu yang tidak bisa ditentukan sehingga menimbulkan perasaan cemas dari seorang ibu karena setiap ibu yang setelah melahirkan, ingin anaknya sehat dan bisa segera di bawa pulang. Hal ini dapat menyebabkan bayi harus tinggal dan dirawat di unit khusus intensif bayi di rumah sakit.

Beberapa ibu yang memiliki BBLR (berat badan bayi antara 1500-2000 gram) dan dirawat di Ruang Peristi RSUD dr. Soeselo Kabupaten Tegal menyatakan dirinya khawatir, cemas, takut, sedih dan kadang menangis melihat kondisinya dan sangat berharap bayinya segera membaik dan segera bisa 
dibawa pulang. Ibu juga mengalami susah tidur dikarenakan harus ikut juga menunggui bayinya serta menginap di ruang intensif untuk dapat setiap saat mengetahui dan memantau kondisi bayinya. lbu yang memiliki BBLR di ruang tersebut mengatakan untuk mengurangi kecemasannya dengan cara mengendong bayinya, selalu disamping bayinya atau dengan mengajak bayinya berkomunikasi. Penelitian ini bertujuan untuk mengetahui pengaruh Emotional Freedom Technique (EFT) terhadap tingkat kecemasan ibu yang memiliki BBLR.

\section{METODE PENELITIAN}

Jenis penelitian ini adalah quasi experimental Rancangan penelitian menggunakan One group pra-post test design. Teknik pengambilan sampel dalam penelitian ini adalah total sampling. Sampel dalam penelitian ini adalah 28 lbu yang memiliki BBLR. Penelitian dilakukan di RSUD dr Soeselo Slawi pada bulan Desember sampai bulan Maret Tahun 2020. Peneliti melakukan pemberian EFT selama 3 hari berturut-turut selama 15 menit pada 1 responden. Pemberian EFT dilakukan oleh peneliti yang telah melakukan pelatihan EFT dan bersertifikasi. Teknik ini menggunakan kalimat penerimaan diri yang dipadukan dengan mengetuk ringan (tapping) titik-titik meridian tubuh untuk mengirim sinyal yang bertujuan untuk menenangkan otak. Teknik tersebut dilakukan dengan mengetuk ringan dengan satu atau dua ujung jari pada titik akupuntur sama efektifnya dengan stimulasi pada praktek akupuntur. EFT disebut juga dengan akupuntur tanpa jarum. Dengan pengetukan dapat menimbulkan respon melalui jaringan sensorik sampai melibatkan saraf sentral. Jaringan saraf berkomunikasi satu dengan yang lain melalui neurotransmitter di sinapsis. Sekresi neurotransmiter ini juga berperan dalam sistem imun sebagai imunomodulator serta perbaikan fungsi organ lainnya seperti pada penyakit psikiatrik (Ningsih et al, 2015).

Menurut Penelitian yang dilakukan oleh Salam (2018) hasil analisis kualitatif setelah diberikan terapi selama 3 hari subyek sudah merasa lebih tenang dari sebelumnya. Saat sebelum diberikan terapi subyek selalu merasa gelisah dengan pikiran negatif. Alat ukur kecemasan menggunakan kuesioner yang diadopsi dari Hamilton Rating Scale for Anxiety (HRS-A) telah dibuktikan memiliki validitas dan realibilitas cukup tinggi untuk pengukuran kecemasan yaitu 0,972 . Alat ukur ini terdiri dari 14 kelompok gejala yang masing-masing kelompok dirinci lagi dengan gejala-gejala yang lebih spesifik, Masing-masing kelompok gejala diberi penilaian angka antara $0-4$, yang artinya adalah nilai 0 tidak ada gejala (keluhan), nilai 1 gejala ringan, nilai 2 gejala sedang, nilai 3 gejala berat, dan nilai 4 gejala berat sekali. Kemudian masing-masing nilai angka dari 14 kelompok gejala tersebut dijumlahkan dan dari hasil penjumlahan tersebut dapat diketahui derajat kecemasan seseorang, yaitu total nilai kurang dari 14 tidak ada kecemasan, 14-20 kecemasan ringan, 2127 kecemasan sedang, nilai 28-41 kecemasan berat dan nilai 42-56 kecemasan berat sekali.nUji statistik yang digunakan adalah uji Wilcoxon dengan nilai $p$ value $<0,05$. Penelitian ini telah uji etik yang dilakukan oleh komite etik penelitian kesehatan Universitas Aisyiyah Yogyakarta dalam melindungi hak asasi dan kesejahteraan subyek penelitian keperawatan.

\section{HASIL DAN PEMBAHASAN}

Distribusi responden berdasarkan usia dapat dilihat pada tabel 1 didapatkan usia responden terendah adalah 18 tahun dan usia responden tertinggi adalah 43 tahun dengan rerata usia responden 28,21 tahun. Manuaba (2012) menyatakan bahwa usia ibu <20 tahun dan $>35$ tahun serta umur kehamilan $<37$ minggu berisiko lebih besar melahirkan bayi dengan berat lahir rendah. Kejadian bayi lahir rendah semakin berisiko terjadi pada kehamilan pertama/primigravida. Penelitian yang dilakukan di Slawi menunjukkan bahwa kasus BBLR lebih banyak ditemukan pada kelompok primigravida daripada multigravida.

\section{Tabel 1. Distribusi Frekuensi Berdasarkan Usia}

\begin{tabular}{|c|c|c|c|}
\hline Variabel & Mean & SD & Min-Max \\
\hline Usia & 28,21 & 7,094 & $18-43$ \\
\hline
\end{tabular}


Hasil penelitian yang dilakukan oleh Salawati (2012) menunjukkan bahwa ibu yang melahirkan pada usia $<20$ tahun dan $>35$ tahun mempunyai peluang untuk melahirkan BBLR 10,7 kali dibandingkan ibu yang melahirkan pada usia 20-35 tahun. Usia ibu saat hamil juga berkaitan dengan usia wanita saat menikah. Wanita yang menikah pada usia dini berpeluang untuk hamil pada usia muda pula. Demikian pula dengan kehamilan primigravida pada usia $>35$ tahun lebih besar terjadinya penyulit dan pre-eklampsi pada masa kehamilan (Prianita, 2011).

Pada penelitian ini usia responden berada pada rentang $18-43$ tahun, peneliti memandang bahwa usia reponden dengan usia tersebut diharapkan kematangan responden dalam berfikir dan bertindak menanggapi perawatan anaknya selama dirumah sakit. Responden dalam hal ini diharapkan mampu untuk membentuk suatu mekanisme koping yang bersifat positif dalam menanggapi setiap permasalahan dan perawatan anak selama dirawat dirumah sakit. Sehingga diharapkan ibu tidak akan mengalami kecemasan.

\section{Tabel 2. Distribusi Frekuensi Berdasarkan Pendidikan dan Pekerjaan}

\begin{tabular}{lcc}
\hline \multicolumn{1}{c}{ Variabel } & f & $\%$ \\
Pendidikan & & \\
SD & 8 & 28,6 \\
SMP & 9 & 32,1 \\
SMA & 9 & 32,1 \\
Sarjana & 2 & 7,1 \\
Total & 28 & 100,0 \\
Pekerjaan & & \\
Tidak Bekerja & 26 & 92,9 \\
Bekerja & 2 & 7,1 \\
Total & 28 & 100,0 \\
\hline
\end{tabular}

Berdasarkan tabel 2 dapat dilihat bahwa sebagian besar responden memiliki pendidikan yaitu SMP dan SMA masing-masing sebanyak 9 orang $(32,1 \%)$, sisanya SD 8 orang $(28,6 \%)$, dan Sarjana 2 orang $(7,1 \%)$. Tingkat pendidikan ibu tidak menjadi faktor risiko terhadap kejadian BBLR. Hal ini karena pengetahuan ibu tidak hanya berpacu pada pendidikan akademik akhir saja. Semakin majunya zaman membuat ibu lebih muda mengakses dan mendapatkan informasi, serta peran tenaga kesehatan yang baik dalam memberikan konseling pada ibu hamil selama kunjungan antenatal.

Menurut Puspitasari (2014) status pendidikan sangat mempengaruhi pola pikir salah satu masyarakat. Tingginya pendidikan masyarakat menjadi penunjang dalam mempermudah untuk mencerna informasi yang diterima untuk dapat dimengerti termasuk untuk menyebarluaskan program penurunan angka kematian bayi dengan menekan angka kejadian BBLR. Pengetahuan ini sendiri biasanya diperoleh dengan pengetahuan tentang kecemasan dan pengalaman yang pernah dilewati. Ketidaktahuan orang tua tentang informasi perkembangan anaknya dapat menjadi penyebab kecemasan.

Peneliti memandang bahwa secara tidak langsung pernyataan tersebut menerangkan bahwa dengan tingginya tingkat pendidikan orang tua, diharapkan nantinya orang tua dapat dengan mudahnya untuk mampu mengerti dan memahami setiap diagnosis yang telah dijelaskan oleh dokter dan melaksanakan perawatan sesuai dengan anjuran yang telah diberikan.

Berdasarkan tabel 2 dapat dilihat bahwa sebagian besar responden tidak bekerja sebanyak 26 orang (92,9\%), sisanya bekerja 2 orang $(7,1 \%)$. Penelitian yang dilakukan oleh Salawati (2012) menyatakan bahwa ibu yang bekerja mempunyai peluang untuk melahirkan BBLR 2,93 kali dibandingkan ibu yang bekerja. Pekerjaan ibu selama masa kehamilan menyebabkan ibu melahirkan bayi premature dan BBLR karena ketika ibu bekerja, waktu istirahat ibu akan berkurang sehingga mempengaruhi janin. Hasil penelitian Puspitasari (2014) menyatakan pekerjaan yang ditanggung oleh ibu hamil dapat memberikan peluang besar untuk terjadinya persalinan dengan BBLR. Keadaan demikian terutama terjadi pada sosial ekonomi yang rendah. Aktivitas fisik beberapa jam tanpa istirahat dapat menyebabkan kelahiran BBLR.Dari hasil penelitian didapatkan bahwa ibu yang tidak bekerja lebih besar frekuensi mengalami kecemasan. Peneliti memandang bahwa ibu yang bekerja tidak mengalami cemas dikarenakan ibu tidak harus melakukan peran ganda yaitu bekerja dan merawat bayi yang sakit.

Berdasarkan tabel 3 menunjukkan bahwa sebagian besar ibu mengalami kecemasan sedang selama merawat bayinya dengan berat lahir rendah di ruang Peristi. Kelahiran bayi 
dengan berat lahir rendah merupakan kelahiran yang tidak diharapkan oleh orang tua. Bayi berat lahir rendah dengan tampilan tubuh bayi yang kecil dan fungsi organ yang belum matang berdampak negatif terhadap psikologis ibu yaitu kecemasan (Suyami et al., 2014).

\section{Tabel 3. Tingkat Kecemasan sebelum dan sesudah dilakukan EFT}

\begin{tabular}{lcccc}
\hline \multirow{2}{*}{ Tingkat Kecemasan } & \multicolumn{2}{c}{ Sebelum dilakukan EFT } & \multicolumn{2}{c}{ Setelah dilakukan EFT } \\
& $\mathbf{f}$ & $\%$ & $\mathbf{f}$ & $\%$ \\
Ringan & 0 & 0,00 & 17 & 60,7 \\
Sedang & 17 & 60,7 & 11 & 39,3 \\
Berat & 11 & 39,3 & 0 & 0,00 \\
Berat Sekali & 0 & 0,00 & 0 & 0,00 \\
Total & 28 & 100,0 & 28 & 100 \\
\hline
\end{tabular}

Berdasarkan hasil penelitian dari Pratiwi (2019) tentang kecemasan pada ibu dengan resiko BBLR menunjukkan bahwa adanya sebagian besar ibu mengalami kecemasan sedang dan berat, kecemasan ini dapat berdampak ibu mengalami penurunan lapang persepsi dan tidak dapat berfokus atau berpikir pada hal yang lainnya sehingga tidak dapat merawat bayinya dengan baik. Respon yang beragam disampaikan oleh para ibu saat ditanyakan peneliti terkait perasaannya selama bayinya dirawat di Ruang Peristi. Sebagian besar ibu menyatakan dirinya sangat khawatir, kadang bingung, ada rasa takut dan sedih melihat bayinya berada dalam inkubator dengan berbagai selang misalnya selang oksigen untuk membantu pernapasan ataupun selang untuk membantu memasukkan cairan/ASI. Beberapa ibu juga tidak bisa tidur dengan nyaman dan nyenyak karena harus ikut menemani tidur di Ruang Peristi, setiap hari mendengar suara alat-alat monitor yang membuat suasana menjadi tegang serta selalu memikirkan bagaimana kondisi bayinya karena kadang kondisinya dapat berubah sewaktuwaktu. Berdasarkan hal tersebut, peneliti memandang perlunya melakukan upaya untuk membantu menurunkan kecemasan ibu supaya ibu dapat lebih tenang dan bersemangat dalam merawat BBLR.

Berdasarkan tabel 3 ini didapatkan data bahwa sebagian besar ibu mengalami penurunan kecemasan dari sedang menjadi ringan setelah dilakukan tindakan EFT. Purwanti et al., (2012) menjelaskan bahwa masa nifas merupakan waktu dimana ibu mengalami kecemasan pasca persalinan terutama pada ibu primipara. Hal-hal yang dapat membantu ibu dalam beradaptasi dalam masa nifas yaitu respon dan dukungan dari keluarga dan teman dekat, riwayat pengalaman hamil dan melahirkan sebelumnya, dan harapan, keinginan dan aspirasi ibu saat hamil juga melahirkan.

Menurut Purnami (2010) adanya perawatan intensif merupakan masalah tersendiri bagi orang tua yang memiliki bayi yang sedang dirawat. Perasaan bersalah, cemas, stress, depresi, dan takut kehilangan bayi sering muncul pada masa ini. Kondisi ini memerlukan kemampuan pribadi dan dukungan dari lingkungan. Respon dan dukungan keluarga dan perawat yang baik dapat membantu suksesnya masa transisi menjadi ibu dan dapat merawat bayinya dengan baik.

Penurunan kecemasan ibu dapat dipengaruhi berbagai faktor diantaranya dukungan dari orang sekitar misalnya keluarga ataupun dari perawat. Dalam penelitian ini, peran dan dukungan perawat sangat besar karena sebagian besar ibu tinggal dan menginap untuk menemani bayinya di dalam Ruang Peristi di ruang tunggu yang sudah disediakan pihak pengelola rumah sakit berdekatan dengan ruang perawatan bayinya. Para ibu setiap hari lebih banyak berinteraksi dengan para perawat. Perawat mempunyai peranan yang sangat penting dalam menggali perasaan ibu, meluangkan waktu untuk mengobrol dengan ibu supaya mengurangi beban pikiran dan perasaannya. Melalui penerapan EFT ini, perawat mempunyai kesempatan waktu untuk berkomunikasi dengan ibu serta memberikan dukungan dan semangat ibu dalam merawat bayinya sehingga kecemasan sebagian besar ibu menurun dari sedang menjadi ringan. 
Berdasarkan tabel 4 menunjukan perubahan skor sebelum dan sesudah diberikan terapi EFT. Perubahan tingkat kecemasan yang bermakna yakni dari 3,39 menjadi 2,39 dengan $\mathrm{p}$ value 0,000 artinya terdapat pengaruh EFT terhadap tingkat kecemasan pada ibu yang memiliki BBLR. Intervensi EFT memiliki paduan unsur teknik diantaranya adalah teknik neuro linguistic program (NLP), psychoanalisa, dan hypnosis yang dilakukan pada saat proses terapi. Teknik tersebut dapat membantu mengidentifikasi terhadap adanya kecemasan serta dapat mengatasi kecemasan yang terjadi pada pasien berdasarkan pada akar permasalahan utamanya melalui proses set up yang dilakukan. Sumber kecemasan tersebut itulah yang akan dijadikan kalimat afirmasi pada saat melakukan tapping. Teknik NLP, psychoanalisa, dan hypnosis yang terdapat pada EFT ini menerapkan prinsip komunikasi terapeutik yang ada pada keperawatan. Terapi EFT ini menggunakan pendekatan teknik komunikasi terapeutik pada tahap persiapan dengan cara membina hubungan saling percaya dan hubungan saling menghormati, sehingga masalah dan sumber kecemasan pasien tersebut dapat diidentifikasi (Trotter \& Gallagher, 2011).

Tabel 4. Pengaruh EFT dengan Tingkat Kecemasan

\begin{tabular}{ccccc}
\hline Tingkat Kecemasan & N & Mean & SD & P Value \\
Sebelum dilakukan EFT & 28 & 3,39 & 0,497 & \multirow{2}{*}{0,000} \\
Sesudah dilakukan EFT & 28 & 2,39 & 0,497 & \\
\hline
\end{tabular}

Damaiyanti (2010) menjelaskan bahwa Teknik komunikasi terapeutik pada EFT juga memberikan keuntungan bagi perawat karena dengan menerapkan komunikasi terapeutik, perawat akan menjadi lebih mudah menjalin hubungan saling percaya (trust) dengan klien sehingga akan menjadi lebih efektif dalam mencapai tujuan asuhan keperawatan yang telah diterapkan serta memberikan kepuasan profesional dalam pelayanan keperawatan. Hal ini juga dapat meningkatkan citra profesi perawat. Kehadiran perawat, sentuhan terapeutik, supporting social, dan konsep spiritual dengan mengajak pasien untuk pasrah dan ikhlas kepada Tuhan terhadap sakit yang diderita juga digunakan dalam tahapan intervensi EFT.

Pasien berada pada keadaan relaksasi pada saat melakukan tapping. Ketukan ada titik meridian tubuh dapat menstimulasi hormone endorphin untuk memproduksi hormon serotonin dan dopamine sehingga membuat seseorang menjadi relaksasi (Thahir., Sulastri., \& Almurhan, 2014). Efek relaksasi ini bisa diamati langsung pada respon responden pada penelitian ini setelah mendapatkan intervensi EFT. Responden terlihat ada yang masih tegang, gelisah, bingung bahkan ada yang sampai menitikan airmata dan menangis saat dilakukan EFT. Namun pada saat dilakukan evaluasi setelah EFT, hampir seluruh responden terlihat lebih tenang dan tampak tersenyum serta terlihat lebih lega.

Hasil penelitian Rokade (2011) menunjukkan saat pasien distimulus untuk mencapai keadaan relaksasi, hormon endorfin ini berikatan dengan reseptor opioid di neuron yang menghambat pelepasan neurotransmitter dan pada akhirnya memblokir sinyal rasa sakit ke otak. Hal ini yang dapat menurunkan efek kecemasan pasien. Pengeluaran hormon inilah yang menekan produksi glukokortikoid sehingga hormon ini bisa membuat tapping yang dilakukan saat terapi EFT, sehingga dapat menurunkan kecemasan pasien. Hasil penelitian lain juga menunjukkan bahwa terapi EFT adalah terapi yang efektif untuk mengatasi kecemasan, depresi, dan gangguan psikologis.

Dalam penerapan EFT ini, para responden diajarkan untuk mengucapkan katakata yang positif (untuk memberikan semangat) misalnya "saya ikhlas dengan kondisi bayi saya, mohon untuk diberikan kesembuhan dan kesehatan", sambil dilakukan tindakan tapping (pengetukan pada area tertentu). Peneliti melakukan beberapa gerakan pengetukan dengan tangan pada area titik tertentu diantaranya di daerah kepala bagian atas, dahi, pipi, dagu serta bagian dada selama sekitar 10 menit. Selama tindakan EFT, ibu duduk bersandar di suatu ruangan yang sepi dan suasananya tenang, kemudian 
memejamkan matanya dan sebagian besar ibu sampai menitihkan air mata. Setelah selesai dilakukan tindakan EFT, para ibu mengatakan merasa lebih tenang, rileks, nyaman serta setelah diukur kembali kecemasannya menjadi ringan. Peneliti menganjurkan ibu untuk dapat menerapkan EFT secara mandiri sambil menunggu waktu menunggui bayinya di Ruang Peristi. Hasil penelitian ini menunjukkan bahwa EFT yang dilakukan peneliti efektif dapat membantu menurunkan kecemasan ibu.

\section{KESIMPULAN}

Rata-rata usia responden 28,21 tahun, tingkat pendidikan sebagian besar SMP dan SMA dan pekerjaan responden sebagian besar tidak bekerja. Ada pengaruh antara pemberian EFT terhadap tingkat kecemasan ibu yang memiliki BBLR dari kecemasan sedang menjadi ringan dengan $P$ value 0,000 . Diharapkan perawat dapat memberikan perhatian lebih kepada ibu yang bayinya di rawat di ruang perawatan resiko tinggi (Peristi), terutama bagi mereka yang memiliki pengalaman minim tentang pelayanan rumah sakit.

\section{REFERENSI}

Bougea, A. M., Spandideas, N., Alexopoulos,E. C., Thomaides, T., Chrousos, G. P., \&Darviri, C. (2013). Effect of the emotionalfreedom technique on perceived stress,quality of life, and cortisol salivary levelsin tension-type headache sufferers: Arandomized controlled trial. The Journal of Science and Healing, 9(2), 91-99.

Damaiyanti, M. (2010). Komunikasi Terapeutik dalam Praktik Keperawatan. Refika Aditama.

Haruyama, S. (2015). The Miracles of Endorphin: Sehat Mudah dan Praktis dengan Hormon Kebahagiaan. Bandung. Qanita.

Hendiyanto, W, A. (2014). Tingkat Kecemasan Ibu yang Mempunyai Bayi BBLR DI Ruang Perinatologi RSUD Dr. Harjono Ponorogo [Universitas Muhammadiyah Ponorogo]. In Skripsi. http://eprints.umpo.ac.id/599/

Hunt, K. N. (2011). The NICU: Environmental Effects of the Neonatal Intensive Care Unit on Infants and Caregivers. Research Paper, 1-30. papers3://publication/uuid/6C029B03-
E32C-4662-A53E-B17A1DF02DA0

Isworo, A., Anam, A., \& Indrawati, N. (2019). Pengaruh Terapi Emotional Freedom Technique (EFT) dalam Menurunkan Tekanan Darah pada Lansia Hipertensi. Gaster Jurnal Kesehatan, 17(2), 154. https://doi.org/10.30787/gaster.v17i2.438

Karatzias, T., Power, K., Brown, K.,McGoldrick, T., Begum, M., Young, J., \&Adams, S. (2011). A controlled comparisonof the effectiveness and efficiency of twopsychological therapies for posttraumaticstress disorder: Eye movement desensitizationand reprocessing vs. emotional freedom techniques. Journal New Mental Disease, 199(6), 372-378.

Laas MJ, de Vries LS, Koopman C, Uniken Venema MM, Eijsermans MJ, B., \& HW, V. S. A. (2011). Postnatal growth of preterm born children $\leq 750 \mathrm{~g}$ at birth. Early Human Development Journal, 87(7), 495-507.

https://doi.org/10.1016/j.earlhumdev.2011 .04.009.

Manuaba. (2012). Amu Kebidanan, Penyakit Kandungan dan Keluarga Berencana Untuk Pendidikan Bidan. EGC.

Ningsih, S,F., Karim, D., \& Sabrian, F. (2015). Efektivitas Terapi Emotional Freedom Technique (EFT) terhadap Kecemasan Pasien Kanker Payudara Stadium II dan III. Cybrarians Journal, 2(37), 1-31. https://doi.org/10.12816/0013114

Pratiwi, W, R. (2019). Hubungan Tingkat Kecemasan lbu Hamil Terhadap Risiko Melahirkan Bayi Berat Lahir Rendah di Puskesmas Rappang. Jurnal IImiah Kesehatan lqra, 7(1), 32-37.

Prianita, A. (2011). Pengaruh Faktor Usia Ibu Terhadap Keluaran Maternal Dan Perinatal Pada Persalinan Primigravida Di Rs Dr. Kariadi Semarang Periode Tahun 2010 [Universitas Diponegoro]. In Kti. http://eprints.undip.ac.id/32864/

Purnami, E, D, R. (2010). Koping ibu terhadap bayi bblr (berat badan lahir rendah) yang menjalani perawatan intensif di ruang nicu ( [Universitas Diponegoro]. In Skripsi http://eprints.undip.ac.id/15039/

Purwanti, D., Fitriasih, \& Isyti'aroh. (2014). Dukungan sosial keluarga dan hubungannya dengan kecemasan ibu primipara dalam merawat bayi berat badan lahir rendah. Prosiding Seminar 
Nasional Dan Internasional, 249-254. https://jurnal.unimus.ac.id/index.php/psn1 2012010/article/view/1458

Puspitasari, R. (2014). Hubungan tingkat pendidikan dan pekerjaan ibu dengan kejadian Bayi Berat Lahir Rendah di RSU PKU Muhammadiyah Bantul. [Universitas 'Aisyiyah Yogyakarta (UNISA)]. In Skripsi. http://digilib.unisayogya.ac.id/1188/1/Nask ah Publikasl.pdf

Riskesdas, K. (2018). Hasil Utama Riset Kesehata Dasar (Riskesdas). https://doi.org/10.1088/17518113/44/8/085201

Rokade, P. B. (2011). Release of Endomorphin Hormone and Its Effects on Our Body and Moods: A Review. Internationa Conference on Chemical, Biological and Environment Sciences, 431127(215), 436-438. http://psrcentre.org/images/extraimages/1 211916.pdf

Saidah, Q., Rustina, Y., \& Nurhaeni, N. (2011). Penurunan Kecemasan lbu dan Perbaikan Status Bangun-Tidur BBLR melalui Perawatan Metode Kanguru. Jurnal Keperawatan Indonesia, 14(3), 193-198.

https://doi.org/10.7454/jki.v14i3.309

Salam, N, M. (2018). Efektivitas Terapi EFT (Emotional Freedom Technique) Untuk Menurunkan Tingkat Kecemasan Pada Narapidana yang Menjelang Bebas di Lapas Narkotika Kelas IIA Sungguminasa [Universitas Negeri Makssar]. In Skripsi. https://onesearch.id/Record//OS3399.102 41\#holdings

Salawati, L. (2012). Hubungan usia, paritas dan pekerjaan ibu hamil dengan bayi berat lahir rendah. Jurnal Kedokteran Syiah Kuala, 12(3), 138-142. http://jurnal.unsyiah.ac.id/JKS/article/view/ 3512/3265

Shari, W. W., Emaliyawati, E., Keperawatan, F., \& Padjadjaran, U. (2014). Emotional Freedom Techniques dan Tingkat Kecemasan Pasien yang akan Menjalani Percutaneous Coronary Intervention Emotional Freedom Techniques and Anxiety Level of Patients undergoing Percutaneous Coronary Intervention. Jurnal Keperawatan Padjadjaran, 2, 133145.

https://doi.org/https://doi.org/10.24198/jkp. v2i3.83.g79

Suyami, Rustina, Y., \& Agustini, N. (2014). Pengaruh Edukasi Terhadap Tingkat Kecemasan dan Tingkat Efikasi Diri lbu Dalam Merawat BBLR. Prosiding Seminar Nasional dan Internasional, 242-248. http://download.garuda.ristekdikti.go.id/art icle. php?article $=1352317 \& \mathrm{val}=426 \&$ title $=$ Pengaruh Edukasi Terhadap Tingkat Kecemasan Dan Tingkat Efikasi Diri lbu Dalam Merawat Bblr

Thahir, A., Sulastri., \& A. (2014). Emotional Freedom Technique. Jurnal Kesehatan, $\mathrm{V}(1)$, 84-89. https://ejurnal.poltekkestjk.ac.id/index.php/JK/article/viewFile/71/6 4

Trotter R, Gallagher R, D. J. (2011). Anxiety in patients undergoing percutaneous coronary interventions. Heart Lung Journal, 40(3), 185-192. https://doi.org/10.1016/j.hrtlng.2010.05.05 4 